\title{
Структурные и минералогические особенности железосодержащих фаз в метеоритах разных типов
}

\author{
С.С. Гонцова ${ }^{1}$, Е.М. Максимова ${ }^{1}$, Е.В. Петрова ${ }^{2}$, И.А. Наухацљий ${ }^{1}$ \\ 1 Крымский федеральный университет имени В.И. Вернадского, просп. Вернадского, 4, Симферополь, \\ Россия, 295004 \\ sgoncova@gmail.com \\ 2 Уральский федеральный университет имени первого Президента России Б.Н. Ельцина, ул. Мира, 19/5, \\ Екатеринбург, Россия, 620002 \\ evgeniya.petrova@urfu.ru
}

Поступила в редакцию 15 ноября 2017 г.

Аннотация. В работе методами оптической и растровой электронной микроскопии, а также рентгеноструктурного анализа был исследован химический и минеральный состав железосодержащих фаз метеоритов разных типов и химических групп. Обнаружены следующие структуры металлических фаз, такие как зерна камасита, тэнита, структура плессита, линии Неймана. В каменных метеоритах на границе раздела металл-троилит выявлены включения металлической меди.

STRUCTURAL AND MINERALOGICAL FEATURES OF IRON-CONTAINING PHASES IN METEORITES OF DIFFERENT TYPES, by S.S. Hontsova, E.M. Maksimova, E. V. Petrova, I.A. Nauhatsky. The chemical and mineral composition of iron-bearing phases in meteorites of different petrological types and chemical groups were studied by optical and scanning electron microscopy, as well as X-ray diffraction. Different structures of metallic phases such as kamacite and taenite grains, plessite structure, Neumann bands were observed. Inclusions of metallic copper were revealed on the border of metal and troilite phase in the stony meteorites.

Ключевые слова: метеорит, металл, камасит, тэнит, минералы метеоритов, рентгеноструктурный анализ, сканирующая электронная микроскопия

\section{1 Введение}

По структурно-минералогическим признакам метеориты делятся на три основные группы - железные, железо-каменные и каменные. Каменные метеориты состоят преимущественно из силикатных минералов, железные - из $\mathrm{Fe}-\mathrm{Ni}$ металла, железо-каменные - из силикатной и металлической фаз. В свою очередь, каждая группа подразделяется на химические подгруппы и петрологические типы (Додд, 1986).

$\mathrm{Fe}-\mathrm{Ni}$ металл, присутствующий в разном количестве в основной массе метеоритов, состоит из тэнита (гранецентрированной фазы самородного никелистого железа космического происхождения $\gamma-\mathrm{Fe}(\mathrm{Ni}, \mathrm{Co}))$ и камасита (объемноцентрированной железной фазы $\alpha$ - $\mathrm{Fe}(\mathrm{Ni}, \mathrm{Co}))$. Большая часть метеоритного металла сформировалась в результате медленного охлаждения тэнита, проходившего со 
скоростями порядка $1-10^{\circ} \mathrm{C}$ в млн лет. По мере его охлаждения происходило зарождение камасита, а при дальнейшем переохлаждении - превращение в дисперсную двухфазную смесь - плессит $(\alpha+\gamma)$ (Рейзенер, Голдштейн, 2003). Разнообразие морфологии плессита является следствием протекания различных фазовых превращений. Изучение структуры металлических фаз помогает определить условия их образования (Гроховский и др., 2004).

\section{2 Объекты и методы исследования}

Методами рентгеноструктурного анализа, оптической и сканирующей электронной микроскопии были исследованы метеориты разных петрологических типов: Сихотэ-Алинь (железный, IIAВ, гексаэдрит), Кампо-дель-Сьело (железный, IAB, октаэдрит), Дронино (железный, Ung, атаксит), Сеймчан (железокаменный, PMG), Челябинск (каменный, LL5), Northwest Africa 869 (каменный, L4-6).

Шлифы образцов метеоритов для исследований на инвертированном микроскопе ZEISS Axiovert 40 MAT и растровом электронном микроскопе FE-SEM ZEISS $\Sigma$ IGMA VP с системой микрорентгеноспектрального анализа INCA Energy предварительно подготавливались по стандартным металлографическим методикам, куда входили распил образцов, шлифовка, полировка и травление $2 \%$ раствором $\mathrm{HNO}_{3}$.

Определение фазового состава метеоритов проводилось с помощью дифрактометра общего назначения “ДРОН-3” методом порошков с использованием медного монохроматического излучения (Cu, $K_{\alpha}$ ). Съемка проводилась в интервале углов от $10^{\circ}$ до $100^{\circ}$.

\section{3 Результаты и обсуждения}

Доминирующей фазой метеоритов Сихотэ-Алинь, Кампо-дель-Сьело и Сеймчан является минерал камасит $(\alpha)$ с концентрацией Ni 5-6.6 wt.\%. Металлическая фаза метеорита Дронино представлена дуплексной формой плессита, образованной дисперсной смесью $\alpha$ - и $\gamma$-фаз $\mathrm{Fe}-\mathrm{Ni}$, с концентрацией $\mathrm{Ni}$ в камасите $(\alpha)$ до 6.8 wt.\%, в тэните $(\gamma)$ до 29.9 wt.\%, в структуре дисперсной смеси $\alpha+\gamma-$ до 11.6 wt.\% (рис. 1a). Такая структура могла быть сформирована в результате дополнительного высокотемпературного воздействия, вызвавшего повторное частичное плавление металла и последующую кристаллизацию с более высокими скоростями, чем исходная.

В металлической части метеорита Сеймчан наблюдается плесситная структура с зоной облачного тэнита (СT) (рис. 1б), состоящего из высоконикелевых округлых островов тетратэнита FeNi в сотовой оболочке камасита (Брусницына и др., 2015). Такого рода структура формируется в результате спинодального распада первичного тэнита (Скотт и др., 2014).

В ряде образцов метеоритов наблюдаются системы параллельных полос - линий Неймана (n) (рис. 2a), возникающих в результате ударно-механической деформации металлических кристаллов при столкновении родительского тела метеорита с другими телами при температуре ниже $600{ }^{\circ} \mathrm{C}$ и космическими скоростями.

В каменных метеоритах металлические включения имеют сложную структуру (рис. 2б). В ряде металлических включений на границах раздела металл-троилит была обнаружена металлическая медь, сформированная также при распаде пересыщенного твердого раствора с образованием тэнита при медленном охлаждении. В метеорите NWA 869 обнаружены металл-троилитовые эвтектики, которые, вероятно, были образованы по диффузионным механизмам в процессе охлаждения металлсульфидного расплава. Учитывая тот факт, что ниже $900^{\circ} \mathrm{C}$ система Fe- $\mathrm{Ni}-\mathrm{S}$ представляет собой два несмешивающихся расплава - Fe-Ni металл и троилит FeS (Ксие и др., 2014), наличие эвтектической металл-троилитной смеси в структуре хондрита свидетельствует о достаточно быстром ее охлаждении из жидкого состояния. 

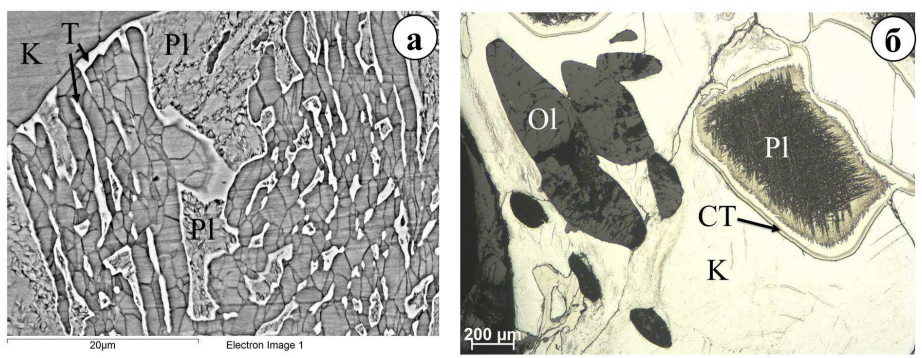

Рис. 1. Металлическая фаза метеоритов: а - Дронино; б - Сеймчан (K - камасит, Т - тэнит, $\mathrm{Pl}$ - плессит, СТ - облачный тэнит, $\mathrm{Ol}$ - оливин)

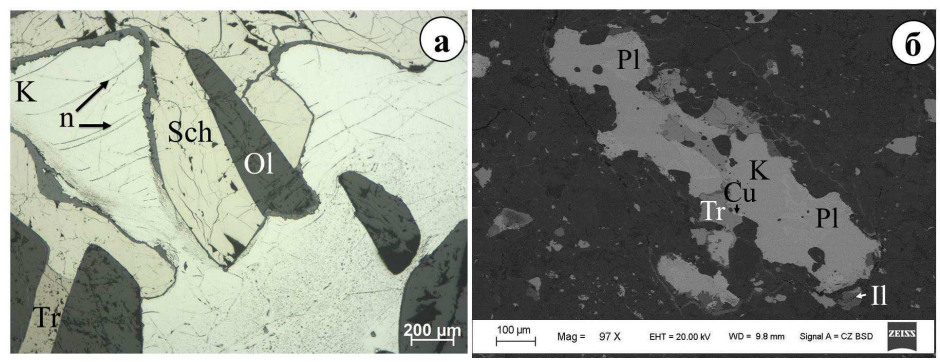

Рис. 2. Структура металла в метеоритах: а - Сеймчан; б - NWA 869 (n - линии Неймана, K - камасит, Pl плессит, $\mathrm{Tr}$ - троилит, Ol - оливин, $\mathrm{Cu}$ - медь, Shr - шреберзит)

\section{4 Заключение}

Химический состав и морфология $\mathrm{Fe}-\mathrm{Ni}$ металла и железосодержащих фаз в исследуемых фрагментах метеоритов разных типов являются индикаторами ударных нагрузок и термального метаморфизма, имевших место в космической эволюции родительских тел исследованных метеоритов.

В исследуемых образцах обнаружены разные структуры металлических фаз: зерна камасита, тэнита, структура плессита, линии Неймана. Сульфидные включения присутствуют во всех образцах. В каменных метеоритах на границе раздела металл-троилит были выявлены вытянутые включения металлической меди.

Авторы выражают благодарность профессору В.И. Гроховскому (УрФУ, г. Екатеринбург) и младшему научному сотруднику Г.А. Яковлеву (УрФУ, г. Екатеринбург) за помощь в организации и проведении ряда исследований.

Настоящая работа выполнена при поддержке Программы развития ФГАОУ ВО "Крымский федеральный университет имени В.И. Вернадского” на 2015-2024 годы в рамках реализации академической мобильности "Сеть академической мобильности «Академическая мобильность молодых ученых России - АММУР," по проекту ФГАОУ ВО “КФУ им. В.И. Вернадского” и Министерства образования и науки Российской Федерации (Проект № 5.3451.2017/4.6).

\section{Литература}

Брусницына Е.В., Гроховский В.И., Яковлев Г.А. // III Международная конференция “Метеориты, астероиды, кометы” и школа молодых ученых “Чебаркуль 2015”. Челябинск: ТЕТА. 2015. С. 126.

Гроховский В.И., Жиганова Е.В., Глазкова С.А., Волосникова А.С., Солодовских М.А. // Вестник УГТУ-УПИ. Современные технологии: проблемы и решения. 2004. № 5(35). Ч. 2. С. 263.

Додд Р.Т. // Метеориты. Петрография и геохимия. М.: Мир. 1986. 
Ксие и др. (Xie X., Chen M., Zhai S., Wang F.) // Meteorit. Planet. Sci. 2014. V. 49. P. 2290.

Рейзенер, Голдштейн (Reisener R.J., Goldstein J.I.) // Meteorit. Planet. Sci. 2003. V. 38. N. 11. P. 1669.

Скотт и др. (Scott E.R.D., Krot T.V., Goldstein J.I., Wakita S.) // Geochim. Cosmochim. Acta. 2014. V. 136. P. 13. 